\title{
第39回日本老年医学会学術集会 一般演題（III）
}

\author{
座長：江藤 文夫, 大川 弥生, 吉田 亮一, 中島 健二 \\ 関沢 清久, 藤島 正敏, 島本 和明
}

\section{4. 温泉地における高齢者のリハビリテーションの} 実態と問題点

群馬大学医学部附属病院草津分院リハビリ テーション部

同内科倉林均

目的：温泉地でのリハビリテーション（リハ）を希 望する高齢者は多く, また旅行先での高齢者の急性疾 患発症も多いが, 遠方からの患者は家族指導, 環境整 備などの面で困難な問題が生じている.今回は, 温泉 地での高齢者のリハの実態を調査し問題点を検討し た.

方法：1985～1996010年間に当院に入院してリハを 受けた 60 歳以上の患者 412 人が対象. 住所, 入院理由, 疾患，障害期間 (障害発生から当院入院までの期間), 入院期間, 介護者, 家族数（患者を含む）を調査し, それぞれ60〜79歳と80歳以上とで比較検討した。

結果：住所は当県内が最多 $(64 \%)$ で，ついで東京 都, 埼玉県, 千葉県の順に多かった. 地元出身者は $41 \%$ にとどまった。疾患別では脳疾患が最多（36\%）で， ついで脊髄脊椎疾患, 骨関節疾患, 呼吸器疾患, 循環 器疾患の順となった. 入院の理由は本人の意志による 入院が最も多く特に 80 歳以上では過半数を占めた。こ れらのうちのほとんどの症例は医師の紹介状を持たず に当院に直接来院した. また他施設の医師の紹介によ る入院はわずか $10 \%$ であった. 平均入院期間は 72 日で あった。介護者が男性または無しの症例では入院期間 が長くなる傾向がみられた。障害期間は 0 日が $21 \%$ と 最多だが 10 年以上にも及ぶ症例が $19 \%$ もられた。介 護者は女性が圧倒的に多いが，80歳以上では嫁（息子 または兄弟の妻）が大多数を占めた，60～79歳では 1 〜 2 人の家族数が多いが 80 歳以上では 3 人以上の家族 数が多数を占めた。

結果：高齢者は阻害発生後も長い年月にわたりリハ を希望し続けているが，その動機と目標は漠然として いることが多く入院は長期化した。誰とも相談せずに 直接来院する傾向があり医師紹介状の無い症例も多く 外来での入院審査は困難であった。高齢者のリ八では
温泉療法を活用することによりリハビリに対する意欲 が増加した可能性も推定された。

\section{5. リハビリテーション病院入院患者における合併} 症の検討

山口大神経内科

柿沼進, 野垣宏, 森松 光紀
山口リハビリテーション病院 福岡 善平

目的：リハビリテーション目的で入院中の患者に発 生した合併症について, その特徵を65歳以上群と65歳 末満群とに分類し比較, 検討する.

方法：リハビリテーション施行目的で山ロリハビリ テーション病院に入院となり演者が担当した症例 117 例を，65歳以上群59例と65歳未満群58例に分類し，そ のうち合併症のためリハビリの中断を含む何らかの治 療, 処置を必要とした症例について, その原因となっ た合併症（原疾患の再発や増悪を含む）をそれぞれ検 討し，その特徴を比較した。

結果：65歳以上群では, 59例中53例が合併症を来た した，その内容は，尿路感染症，細菌性胵炎，転倒に よる骨折など原疾患と直接関係のない疾患が多く, 原 疾患と関係があると思われるものとしては幻覚, 詭妄 状態が多かった。一方，65歳末満群では，58例中44例 が合併症を来たした，その内容は, 尿路感染症など原 疾患と直接関係のない疾患は65歳以上群に比べて少な く, てんかん発作や脳梗塞の再発など原疾患に関連す るものが65歳以上群に比べて多い傾向があった。転倒 による骨折・外傷, 幻覚, 譫妄状態は 1 例もなかった。

老年医学的意義：老人医療費の急増が問題とされる 現在, 老人医療の一部はいわゆるまるめ医療への転換 が推進されつつある.しかし，比較的安定した状態で リハビリテーションを施行中の患者においても, 高齢 者は感染症などによって全身状態が悪化する危険性は 高く, 必要に応じて全身的な精密検查や治療が求めら れる場面に遭遇することは多い。そのため, 高齢者に おいてはリハビリテーション施行中といえども, 常に 全身状態の管理に配慮することが重要である. 
76. 障害を持つ高齢者における QOL の研究（4） 一脳卒中患者・配偶者に対するリハ・プログラムの効 果

帝京大学市原病院り八科

$$
\begin{aligned}
& \text { 大川 弥生, 太田喜久夫, 小池 知治 } \\
& \text { 竹内 正人, 上田 敏 }
\end{aligned}
$$

目的：我々は1988年以来「いかにQOL を向上させ るか」という基本的立場に立ってQOL に関する一連 の実証的及び理論的な研究を行ってきた。今回は脳卒 中患者の配偶者の QOL について検討した。

対象と方法：I；1）入院り八施行後自宅生活中の 脳卒中初回発作後男性片麻痺患者で, 脳卒中発作後調 查時まで新たな麻痺や運動機能障害の出現がなかっ た，56名の65歳以上の患者自身(男性32名，女性24名) とその配偶者を対象とした。我々が開発した「包括的 QOL 評価法」（信頼性・妥当性ともに検討済）を用い, 客観的 $\mathrm{QOL}$ (生命の質, 生活の質, 人生の質の 3 レべ ル）と主観的 QOL を, 発症前・発症後最悪時・現在・ 将来の 4 時点で評価し，その結果に影響する因子につ いて検討した。2）若年脳卒中患者69名とその配偶者に ついても同様の検討を行い, 比較した．II；1)の結果 に基づき，我々がこれまでその効果の実証的検証を 行ってきた「(個々の患者の QOL 向上にむけた）積極 的リハ・プログラム」について，特に家族の QOL 向上 にむけて更なる綿密化を行い，1）の群との QOL の比 較を行った。

結果：I；1）配偶者の QOL も患者本人と同様に, ほぼ全項目で発症後低下し, その後改善するが,「現在」 においても発症前よりも低值で, 将来予測は「現在」 よりも低值を示す.2）配偶者の発症による QOL の低 下は, third-party handicap の反映が大きいと考えら れた。II；リハ・プログラムの改善によって，患者及 び家族ともに QOL は改善した。特に社会的 QOL の向 上は著しかった。

\section{7. 脳卒中患者前脛骨筋の筋エコーによる廃用性筋} 萎縮の経時変化の検討一加齢の影響を中心に一

七沢リハビリテーション病院脳血管センター 神経内科 ${ }^{1)}$, 検査科 ${ }^{2)}$, 内科 ${ }^{3)}$, 東京医大老年科 ${ }^{4)}$ 馬原孝彦144) 平林 泰信 ${ }^{2)}$ 菊川昌幸 ${ }^{3) 4}$ 金谷 潔史 ${ }^{4)}$ 榎本 睦郎 ${ }^{4)}$ 浅野 哲-4) 岩本 俊彦4) 高崎 優 ${ }^{4}$ 岩淵定 ${ }^{11}$

目的：脳卒中片麻痺患者の健側および患側の前脛骨 筋（ATM）での廃用性筋萎縮（DA）の評価における
筋エコーの有用性は，本学会他においてすでに報告し ている.DAによる筋肉内 echogenicity の上昇を, 六 段階評価 $(\mathrm{EG})$ ですでに示した。今回は EGの経時変 化を力齢の影響を中心に検討した。

対象および方法：リハビリテーション専門病院に入 院した脳血管障害患者で, 笳エコーでATM の経時変 化を観察した以下の18症例を対象とした. 男 11 , 女 7 , 平均年歯 56.3 歳. 30 歳代 1 例, 以下 $40-4$ 例, 50-6 例, 60-5 例, 70-1 例, 80-1 例. 脳出血 9 例, 脳 梗塞 6 例, クモ膜下出血 3 例. 片麻痺 13 例（右 4 , 左 9 ), 不全四肢麻痺 5 例. 発症から初回検査までの期間 $2 \sim 13$ 力月 (平均 4.3 力月), 経過観察期間 $1 \sim 8$ 力月 (平均3.6力月).

$7.5 \mathrm{MHz}$ プローブを用い，Bモード断層エコーに て, 背臥位で両側 ATM の echogenicity の変化を検討 した。安静時筋幅，最大収縮時筋幅も計測した。

結果：初回検查時に健側・患側ともに echogenicity が正常（EG1）だった例は39歳と46歳の男性 2 例のみ で，最終検査まで EG1であった。

初回検查時 echogenicity の異常を認めた16例で, 中 等度以上の所見 (EG3a 以上) を少なくとも一側で認め た例は 7 例（40歳代 1 例，50-2 例，60-4 例）で, 症例数が多い40から60歳代では，加歯による増加傾向 を認めた。

経過観察で echogenicity の低下（改善）を示した例 は 4 例 $(40-1$ 例, $60-3$ 例), 不変 6 例 $(40-2$ 例, $50-2$ 例, 60-1 例, $70-1$ 例), 上昇 (増悪) 6 例 (50-4 例，60-1例，80-1 例)であった。少なくと も60歳代までは筋肉内異常 echogenicity はリハビリ テーションにて改善する可逆的変化であった。上昇例 の多くは阻害因子によりリハビリテーションが中断ま たは充分でない症例であった。

老年医学的意義：筋肉エコーは，高齢者の ADL を 悪化させる要因のひとつであるDAの治療評価判定 に有用である。

当研究の一部は住友海上福祉財団の助成を受けた。

\section{8. 我々の高齢障害者の家屋改造に関する指導方式}

いわてリハビリテーションセンター

花籠 良一, 高橋 明

はじめに：本県における中核施設としての当セン ターの四大任務として早期の医学的リハビリ, 調査研 究, 教育研修, ならびに地域リハビリ支援があり, そ のうち特に地域リハビリと関連して家屋改造指導を実 
施している.

対象と方法：業務は二大別され，一つはこのテーマ に関して専門家を招いての公開講座の類である．今回 は第二である個々の患者家屋改造の指導についての心゙ る. 対象であるが，当センターは往診の型式はとれな いが, 入院例が, 退院後も障害者家屋を必要と認めた なら退院前に OT が患家に行き，家族，工事関係者， 時により保健婦とか役所職員などを指導助言する方式 である.

結果：当センターは開設して 3 年が経過した。 入院 のほぼ $80 \%$ は脳卒中であり,在院日数の平均は 120 日で ある。退院時，な抢後遺症のある症例の $35 \% 67$ 例に家 屋評価をし改造の指導をした．脳卒中のほか比較的少 ないが脊損, 外傷, 骨関節疾患, 神経難病などがある.

単なる高㢼化のみに由来する ADL などの能力低下 例については，原則的に我々病院の担当外のことかも しれないが，原疾患と老化が密接に関連してくる．何 年も先のことを予想して指導と助言をしなければなら ない. 退院後にも長期予後的には機能 Up もあり得る 若年障害者用への家屋改造と若干おもむきが異なって くる. 67例の平均年齢は61.7歳であるが脳卒中のみで はもっと高龈となる。

改造の項目では手すりの取り付け，段差・スロープ, 風呂, トイレその他の順となっている，地方自治体に もよるが身体障害者 2 級以上では工事費 150 万円で の $1 / 3$ は県, $2 / 3$ まで市町村が援助する.

考察：高歯者, 障害者用の住宅改造もしくは新築で もこの問題は QOL と関連し重要である，病院のリハ ビリ効果を退院後も維持するためにも必要である。そ して経済的，行政的要素が大で，また家族の意識が大 切である。

79. 大腿骨頸部骨折患者に対して早期より社会的背 景を念頭においたアプローチの必要性に関する一考察 一杖歩行開始から退院までの期間による検討一

神戸大学医学部保健学科

$\begin{array}{cc}\text { 日高 } & \text { 正巳, 米田 稔彦, 武政 誠一 } \\ \text { 嶋田 智明, 石川 齊 }\end{array}$

石川病院安藤 義博

はじめに：大腿骨頸部骨折の退院に際して, 移動能 力の獲得の影響は大きい。しかしながら, 高齢者の場 合には移動能力以外の影響を受けることも少なくな い. 今回，杖歩行開始から退院までの期間より，早期 から社会的背景を考慮しアプローチする必要性につい
て検討したので報告する。

対象：当院で過去二年間に Hip Screwによる骨接 合術を実施した大腿骨頸部骨折患者 12 名のうち，杖歩 行を獲得しえた症例 8 名（男性：5名, 女性：3名, 平均年噛70.9 16.53 歳）を分析対象とした。

結果：杖歩行開始から退院までの期間について検討 してみると，2つのグループに分けられた。期間が短 かったグループでは, 杖歩行開始までは院内での歩行 量確保の観点より歩行器を用いていたため, 杖歩行開 始が遅くなっていたが，機能的に大きな問題がなかっ た。一方，期間が長かったグループでは，疼痛や筋力 回復の遅延, バランス能力の不良によって杖歩行開始 も遅延し，全体としてプログラム進行が緩徐であった。 それに加えて, 屋内移動方法, 通院手段, 家族状況, 居住環境等の問題のため, 杖歩行獲得から退院までが 長期化していた.

考察: 退院については, 社会的入院という言葉が示 すように，それぞれの患者の有する社会的問題が大き く影響している．社会的背景の問題がない場合には, 歩行器による歩行量が確保されていれば杖歩行開始が 遅れたとしても，全体として短期間の入院で斉むこと となる。しかし，社会的背景の問題を有する場合には， 杖歩行獲得後も入院を必要とする場合が多い. 今回の 結果では，家族介護が困難なため退院ができないと いったケースは見られなかったものの, 屋内移動方法 の検討及び通院手段の検討を早期より実施しておくこ とでもう少し早く退院できたのではないかと考える.

\section{0. ゼラチンタイプ食品を用いた長期臥床患者に対 する摂食・嚥下機能訓練の有用性について}

尽誠病院栄養部, 歯科 ${ }^{1)}$, 内科 ${ }^{21}$

鈴木 康仁, 吉友 信孝 ${ }^{11}$ 中嶋 良行 ${ }^{21}$ 橋本 眞徳 ${ }^{21}$

目的：脳血管障害後遺症及び老年性痴呆等の疾患の ため， 6 力月以上の長期臥床状態にあり，経静脈ない しは経腸栄養を施行されている患者に対し，ゼラチン タイプの食品（ムース食）を用いて摂食・臙下機能訓 練を行い，その有用性を検討した。

方法：対象は84名 (60～101歳まで平均83.2歳)の患 者でそのうちわけは脳梗塞44名, 脳出血11名, くも膜 下出血 $(\mathrm{SAH})$ 1名, パーキンソン病 3 名, 水頭症 1 名, 老年性痴呆 24 名であった。今回使用したムース食 は本院栄養部が独自に開発したもので, 容易に摂取で

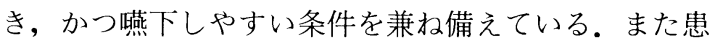


者の嗜好に配慮して改良を重ね，厳選された 8 種類の ムース食を用いた，機能訓練の手順はムース食による 口唇刺激から開始し, 開口が可能となった段階で口腔 内に投与し, 咀嚼, 嚥下運動へと発展, 展開した。

結果：患者84名のうち，72名（85.7\%）に扔いて経 口搨取が可能となった（普通食への移行15名，ムース 食単独27名，ムース食と経静脈ないしは経腸栄養併用 30名)。一方，効果が認められなかった0は12名 (14.3\%) で疾患別に見ると, 広範囲の脳梗塞 6 名, 脳 幹部梗塞 2 名, SAH 1 名, 広範囲の脳出血 1 名, 老年 性痴呆 2 名であった。以上より，重症の脳血管障害を 有する患者では効果はあまり認められないが，老年性 痴呆やさほど重症でない脳血管障害等の疾患では十分 な効果を期待できることが確認された。

結論：攝食・臙下障害を有するために，経口攝取が 困難となった長期臥床患者に対し，攝食・噁下機能訓 練を行い, 経口摄取を可能とすることは，患者の ADL の拡大及び QOL の向上に直接結びつく。この機能訓 練に有用な役割を果たすのが本院独自開発の特製ム一 ス食であり，今後も積極的に広く応用していきたいと 考えている。

\section{1. 嚥下リハビリ食としての高カロリーゼリーの試}

\section{み一点滴, 胃ゾンデ抜去を目指して一}

東京大学老年病, 埼玉回生病院*

須藤 紀子, 鳥羽 研二, 江頭 正人
長野宏一朗, 阿古 潤哉, 杉本 直太
吉栖 正雄, 大内
尉義, 原 鳥 美津子*
禈圭*

高齢の誤嚥性肺炎を繰り返す症例では，IVH，経鼻 胃栄養や胃瘦造設などがとられることが多いが，これ らは十分な曣下リハビリを施行後の選択とすべきであ る、嚥下リハビリの過程で, 半固形食が用いられるが, 市販のゼリーやヨーグルトなどを使用するため，あく まで補助栄養食にとどまって抢り，粥食にステップ アップして失敗する例も少なくない，今回ゼリ一食の 材料に市販の医療用高力ロリ一栄養食を使用し，長期 的なリハビリ食としての可能性を検討した。

方法：入院嚥下障害症例（男 4 名，女 4 名：平均年

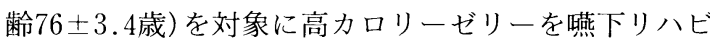
リ食として用い，開始前，1 力月， 3 力月の栄養経路 の変化, 水のみテストの変化, ADL の変化を比較検討 した。ゼリ一食は少量から開始し，体重に応じ $800 \sim 1,200$ カロリー以上摂取出来た場合に点滴や経鼻
ゾンデを抜去することとした。

結果： 3 力月後 8 例中 6 例は点滴や胃ゾンデがはず れ, 3 例は全粥食, 3 例はゼリー食が経口摂取可能と なった. 失敗例は 1 例が IVH 管理， 1 例は胃ゾンデ管 理となった． 5 秒以内に $10 \mathrm{~m} /$ の飲水が完了するのが 正常とされる水のみテストでは，飲み終わるまでの時 間, 飲み分ける回数には変化なく, 成功例ではむせが $1 / 3$ に減少し飲水後の肺雑音は $1 / 2$ に減少した。開始時 には 6 例が葠たきり， 2 例が起座可能の状態であった が, ADL は成功例では 6 例中 4 例 $(66 \%)$ に改善がみ られ， 1 例は自力歩行， 1 例は車イス自力移動可能と 著明な改善を示した。また成功例では, 経過中発熱の エピソードは殆どみられなかった。一方，失敗例は 1 例は経過中誤嚥性肺炎を繰り返し，1例は口腔内残留 が多く，2例とも寝たきりのままであった。点滴抜去 などのため抑制を余儀なくされていた 4 例中 3 例は抑 制解除となった。

結論：高カロリー栄養食を用いたゼリーは高齢嬩下 障害症例の ADL，QOL を高める長期嬿下リハビリ食 として有用である。

\section{2. 老人病院におけるケアプランの認知度（特に MDS-RAPs に関して）及び実施の現状について} 名古屋大学老年科 益田雄一郎, 山本 隆一, 神田茂 三浦 久幸，伊芠 弘之，井口 昭久

目的: 公的介護保険の中で, 重要な問題と思われる ものに要介護度認定及びケアプラン策定の問題が挙げ られる。また公的介護保険の給付対象になるとされて いるものの一つに老人病院（特例許可老人病院, 介護 力強化型老人病院を含む) が存在する. 現在ケアプラ ンは老人医療入院管理料 1 を採用している老人病院お よび老人保健施設施設料 2 を採用している老人保健施 設で義務づけられているが，その現状についてはあま り知られていない，義務づけられていない施設におい てのケアプラン実施状況, そしてその方法論の一つと しての MDS-RAPs の認知度などケアプラン実施の現 状について，今回我々は調査した。

方法：愛知県全県下において老人病棟入院管理料 (いわゆる定額制) を選択している老人病院は, 平成 8 年 7 月現在 46 施設存在する。そのうちの 40 施設につい て面接調査を行った。面接の対象となったのは施設長, 事務長，看護婦長の方々であった。

結果：(1) ケアプランを一部にせよ実施している施 
設が27施設 $(67.5 \%) ，(2)$ ケアプランの策定に参加し ている職員の職種は看護婦が27施設 $(100 \%)$ ，医師が 22施設 $(81.5 \%) ，(3)$ 何らかの形で包括的なアセスメ ントを実施している施設が25施設 $(62.5 \%) ，(4)$ MDS-RAPs の存在を知っていた施設が22施設 (55\%)，（5）実際に MDS-RAPSをケアプランに利用 している施設は15施設 (37.5\%) ということであった。

今回我々が調査した施設の全ベッド数は約 5,000 床 にもおよび，高齢者の長期介護施設として重要な役割 を果たしている．公的介護保険が導入された場合，ケ アプランの義務化が予想されるが，それに対してこれ らの施設が充分な準備をしているとは言い難く，また その方法論の一つである MDS-RAPs も充分に認知さ れていないことが明らかとなった。

\section{3. 老人病院入院患者の入院前生活背景と身体状況} 一高齢者アセスメント表 (MDS) から一

京都東山老人サナトリウム，京都府立医大神 経内科*

高倉 幸次, 酒井 泰一, 森敏*

目的：老人病院入院患者を対象として，i）障害性 成人の状況，ii）入院前の生活場所，iii）世带構成を, 高齢者アセスメント表（MDS）から調査した。

対象と方法：対象は，平成 7 年 1 月以降に MDS 評 価を行なった東山老年サナトリウム在院患者 1,295 名 である。男は 348 名 (27\%)，女は947名 (73\%) である。 年齢は，80歳代が $52 \%$ で約半数を点め，70歳代 $23 \% ，$ 90歳代15\%の順であった。痴呆性老人は, 問題領域「痴 呆・認知障害の検討」が選定され，かつ「移動」の障 害度が「部分的な援助を要する」以下の者とした。寝 たきり老人は，「移動」の障害度が「広範な援助を要す る」以上の者とした。

結果：対象者のうち，族呆性老人は $42 \%$, 寝たきり 老人は $40 \%$ を占め，後者の $86 \%$ が疾呆を伴っていた。 過去 5 年間の変化を見ると，痴呆性老人が漸次増える 傾向が見られた．全対象者の入院前生活場所は，自宅 $40 \%$ ，病院 $51 \%$ ，福祉施設 $8.3 \%$ であり，過去 5 年間の 変化を見ると,施設の比率が $1.5 \%$ から $11 \%$ へと増える 傾向が見られた。

痴呆性老人の入院前生活場所は, 自宅 $48 \%$, 病院 $42 \%$, 福祉施設 $9 \%$ であった。一方, 寝たきり老人は, 自宅 $31 \%$, 病院 $61 \%$, 施設 $8 \%$ であった。両者を比較 すると，痴呆性老人は施設からの入院が多く，葠たき
り老人は病院からの入院が多かった．施設からの入院 については, 痴呆性老人は, 老健施設 $48 \%$, 特養ホー ム $40 \%$ と，両者ほぼ同数であるのに対し，寝たきり老 人は老健施設 $85 \%$ ，特養ホーム $12.5 \%$ と，老健施設に 集中していた。

世帯構成は，老夫婦のみは $11 \%$, 独り暮しは $30 \%$, 家族との同居は $59 \%$ であった。過去 5 年の変化を見る と，独り暮らしが $42 \%$ から $25 \%$ に減少し，家族との同 居は49\%から63\%に増えていた。

\section{4. 特別養護老人ホーム新入所者における介護の状 況，心身の医学的状況についての追跡的研究}

浴風会病院内科 吉田 亮一，大友 英一

目的：特別養護老人ホーム（特養）に同時入所した 144名を対象として, 入所時より 6 年間継続して, 種々 の調査を実施した。介護や医療について 6 年間の変化 を分析しそそれにより同時に特養の介護や医療を供給 された状況での，長期間に及ぶ経年的および病態的変 化を明確にし，特養のありかたを考察した。

方法：特養に同時入所した144名を対象に, 入所時よ り 1 年間隔で 6 年間継続して下記の如く調査を実施し た。

対象者の 6 年間の動向を, 日常生活動作 $(\mathrm{ADL})$, 病 態, 知的精神活動, 脳波, 頭部 CT, 血液, 尿検查を 6 年間の経過で調查する.

結果：1）動向としては死亡退所が多く認められ，4 年間で新入所者は $55.5 \%$ の死亡があり，年間の入院率 は，30〜40\%台であった。病態別の死因率としては， 脳血管性痴呆 $84.6 \%$ ，アルツハイマー型老年痴呆 65.1\%で高率であった。2）ADL の基本的な動作は 1 年目は上昇し， $2 \sim 3$ 年目は軽度低下， 4 年目以降は 上昇傾向を認めた。3）精神面の 6 年間の経過観察で は, 痴呆者は減少したが, 痴呆の程度は進行しSDAT の進行が考慮された。4）血液検査は時間の経過で著変 なかった，異常值に関しては適切に入院加療が，実施 された結果であった。5）CT 診断は 6 年間で著変な かったが，それは CT で新たな知見を呈する症例は， 入院した結果である. 脳波は入所後より 3 年目までは 悪化しており，4 年目は脱落者の影響で，異常例は軽 度減少した。

全体的な結果としては，基礎疾患により種々の調査 結果が，異なる傾向が示された。これは特養における 介護体制や医療体制について，病態別の必要性を考え させるものであった。 


\section{5. 鲤たきり老人の発症年齢と予後}

東北大学老人科

$$
\begin{aligned}
& \text { 小坂 陽一, 中川 挀磨 } \\
& \text { 荒井 啓行, 佐々木英忠 }
\end{aligned}
$$

今回我々は, 高齢者の ADL が低下し, 寝たきり状態 となった時点より死亡するまでの生存期間について調 查した。1994年 1 月より1996年 7 月までの期間，老人 病院入院中死亡した 108 人（男性 48 人，女性 60 人）につ いて，主病，ADL，寝たきりとなった原因疾患，㾛た きりとなった時期, 死亡原因等を調査した。寝たきり 状態の定義は, 座位による体位保持, 食事, 排泄の全 てが能動的に不可能な状態とした，寝たきり発症後の 生存期間は, 発症年歯令の上昇と共に短縮を認めたが, 特に75歳以上においては，それ以下に対して有意に短 縮した。寝たきり状態となった主病としては，脳血管 障害が $44.7 \%$ 占めた。死し原因としては，肺炎が $32.8 \%$ と最も多く, 次いで原因不明の感染が $18.8 \%$ を 占め, 感染症全体としては，56.3\%となった。

高歯化社会を迎えて寝たきり状態の予防は，急務で あると言われている。

今回の結果より，少なくとも寝たきり状態の発症が 高齢であるほど, 特に75歳以上の発症に打いて, その 期間が有意に短縮されることが確認された。

また，桨たきり発症後は，誤嚥性肺炎を中心とする 感染症の予防が重要であると考えられた。

\section{6. 老人施設における初期臨床研修の有用性}

東京都多摩老人医療センタ一内科 津鳥 隆也, 溝口環, 井上 剛輔 同リハビリテーション科福原美智子

目的：厚生省により1994年 4 月から認められた老人 施設での臨床研修を, 我々は 2 年間行ってきた。その 経験から, 施設利用の初期臨床研修の有用性につき検 討したので報告する。

方法：養護及び特別養護老人ホームを利用して，研 修医 5 名に我々独自の施設医療研修プログラムに沿っ て研修を行った. 研修期間は 1 週間 3 名, 3 力月 1 名, 12 力 1 名と, 短期と長期に分かれた。研修は指導医 が各研修項目について実地指導を行うほか, 多くの時 間を単独で利用者や施設職員に接するようにさせた. また研修中は頻回に論議の場を持った，研修終了後に 研修成果と感想を報告させた。報告書と研修中の接触 から老人施設における臨床研修の成果を判断した。

結果：医療機関での研修では病気に主たる注目を置
いたが，施設研修では老人の生活背景にも大きく注目 した事が全研修医共通の収穫であり，さらに在宅ケア や介護保険等にも関心が及び，ゴールドプランへの意 見も多く聞かれた。また 12 力の長期研修医において は, 高齢者の生理的特徵や病態について頻回に論議が 持たれた。

考察：老人の生活背景を意識するようになったり， 老人の福祉，保健にも関心が及ぶ等，医療対象を中心 として視野が拡がるという成果が施設研修で得られ た。しかし長期の研修医を除いては老人特有の生理や 病態などの把握は充分とは言えず，これには時間的要 素が不可欠と思われた。研修医が，将来老人医療や施 設医療に接しない場合でも，全人的な医療を行う土台 作りとして，卒後の初期研修期間中に老人施設での臨 床研修を体験する事は非常に有意義であると考える。

\section{7. 神経疾患患者の在宅療養阻害因子に関する検討 一高齢者における特徵一}

聖マリアンナ医科大学横浜市西部病院神経内 科

野口 克彦, 高橋 洋一, 原 良太郎 聖マリアンナ医科大学第三内科

田野 啓子, 斎藤 宣彦

目的：神経系慢性疾患患者における在宅療養導入可 否の客観的評価法と各阻害因子について検討してき た，本報告ではこれら患者における在宅療養阻害因子 の高齢にともなう特徵について検討した。

対象：神経系慢性疾患患者79例で, 66歳以上(66〜86 歳, 平均 75.8 歳) 51 例と 65 歳以下 $(27 \sim 65$ 歳, 平均 52.2 歳）11例。

方法：既に報告した，計35項目からなる在宅療養を 阻害すると考えられる因子(痴呆, うつ状態, 球麻痺, 膀胱直腸障害, など臨床症状 14 項目, 姿勢保持, 移動, 入浴動作，着衣動作，など ADL 7 項目，経済状況，住 居環境, 疾患受容度, 目的意識, など社会的因子 8 項 目，介護者の健康状況，疾患理解度，時間的余裕，在 宅療養への意欲，など介護者因子 6 項目）を条件の悪 い程低值になるように 4 段階に分けて上記患者退院時 に各々評価した．対象を65歳以下の群と66歳以上の群 に分け，また各々をさらに在宅療養が可能であった群 と不可能であった群に分けて retrospective に評価比 較した，在宅療養可否の判定は，退院後少なくとも 3 カ月以上在宅療法が継続できた例を在宅可とし，はじ めから施設介護になった例や，いったん在宅療養に 
なっても 3 カ月以内に再入院となったり施設介護に なった例を在宅不可と判定した。

結果：65歳以下の群全体と66歳以上の群全体との比 較では，66歳以上の群で知呆の項目において有意に低 値であったが，それ以外の項目では有意な差はみられ なかった。65歳以下の群の中の在宅可否の間では，栄 養管理, 球麻痺, 膀胱直腸障害, 合併症と, ADL のす べての因子で在宅不可の群で有意に低值であったが, 社会的因子，介護者因子では有意な差は見られなかっ た. 66歳以上の群では, 球麻痺, 膀胱直腸障害, 合併 症, 介護者の疾患理解度, 在宅への意欲, の項目で有 意に在宅不可群で低值であったが, ADL では有意な差 はみられなかった。

\section{8. 在宅高齢者の慢性疾患が日常生活へ与える影響} 京都府立医大神経内科

$$
\begin{aligned}
& \text { 狐野 一葉, 上田 祥博 } \\
& \text { 田中 直樹, 中島 健二 }
\end{aligned}
$$

目的：京都府京北町において65歳以上の高齢者健康 調査のアンケートを解析し，在宅高齢者において種及 の疾患が日常生活へ与える影響を調査した。

対象：65歳以上の高齢者でアンケートに回答した 1,436 人。

方法：痴呆の代表的症状 9 項目につき家族に質問し （はい=2，ときどき $=1$ ，ない $=0)$, 合計を痴呆症 状の強さの指標とした。9 項目とは, 日時の失見当, 場所の失見当, 短期記憶の障害, 夜間の興奮, 幻覚, 服装の乱れ，家族との意志の疎通障害，人付き合いの 悪さ,できていたことができなくなる等の項目である. 本人に対しては脳卒中, 高血圧, 糖尿病, 心臟病, 眼 科疾患, 頸椎・腰椎疾患の有無を質問した。さらに, 本人に日常生活に対する質問（世の中のことに関心を 持っているか, 家族の役に立っていると思うか, 生活 に満足しているか）を施行した。痴呆症状の強さ・各 疾患の有無が日常生活に対してどのように関連してい るかを検討した (multiple logistic test).

結果：世の中への関心のなさには, 痴呆症状の強さ $(\mathrm{p}<0.05)$ が関連していた。家族の役に立っていない と思うことには, 痴呆症状の強さ, 眼科疾患 $(\mathrm{p}<$ $0.05)$, 脳卒中 $(\mathrm{p}<0.05)$ に罹患している等の因子が 関連していた。生活に不満であることには, 痴呆症状 の強さが関連していた（ $<<0.05 ）$.

考案：在宅高齢者における日常生活の充実感には痴 呆症状が深く影響していた．在宅高齢者においては痴
呆症状に対する周囲からの適切な働きかけが必要であ る.

\section{9. 高齢期にある者の配偶者と死別後の心理変化} 鹿児島大学医療技術短期大学部

奥祥子

目的：配偶者の死に対する衝撃とその影響は極めて 大きく，生活上の重大なストレスになることは，既に 報告されている。しかし，配偶者との死別を経験した 者のその後の心理変化に関する報告は少ない，そこで 本研究は，高齢期に配偶者と死別した経験をもつ者の 死別後の心理変化について，その特徴を明らかにする ことを目的とした。

方法：満60歳以上で配偶者と死別した経験をもつ者 10名（男性 5 名, 女性 5 名, 平均年歯69.4歳）を対象 に聞き取り調查を行った。調査期間は，1995年 2 月か ら 7 月までの 5 力月間である。調查は, 死亡時から 1 週間, 四十九日, 一周忌まで, およびそれ以降の葬送 儀礼時を中心として, 配偶者を亡くす以前から現在に 至るまでの感情や生活の変化について聞き取りを行っ た。調査内容を，生前の夫婦の関係と死亡時の状況の 二要因に分けて検討を行い，さらに聞き取り対象者の 言葉から，夫婦の関係を行動次元および情緒次元の両 側面から自立と依存に大別し，死亡時の状況に関して は，配偶者との死別が突然で予測できなかった場合と 予測可能な場合に分類して検討した.

結果：死別後の心理変化には, ショック, 否認・怒 り・後悔, 諦め, 奮起の四段階の過程が認められた. 特に, 葬送儀礼時, 初七日まで, 四十九日まで, 一周 忌まで，およびそれ以降と密接に関連していた。心理 変化にはほぼ一定の順序性が認められたが, 順番に次 の段階に進行するのではなく，行き来を繰り返しなが ら徐々に進んでいくことが明らかとなった。また生前 の夫婦の関係や死亡時の状況は, 第二段階（否認・怒 り・後悔，諦め）に影響を及ぼしていることが明らか となった。

結語：高齢期にある者の配偶者と死別後の心理変化 は,葬送儀礼と密接に関連していることが示唆された。 


\section{0. 特別養護老人ホームでのターミナルケアを考え} る

兵庫県立総合リハビリテーションセンター内 科

石原 健造, 鹿住 敏 目的：厚生省の統計によると, 在宅死の比率は平成 5 年に $19.8 \%$ と最低を記録した後，漸増の兆しを示し ている．特養においても不必要な延命治療については 疑問もあり，特養を終のすみかと考えている高齢者も 多いと思われターミナルケアの必要性を痛感する.

方法：当センター特養 (定員 100 名) における平成 5 年から 9 年現在までの死亡退所者の検討を行うととも に，ケアワーカー 28 名に対しターミナルケアに関する アンケート調查を実施した。

結果: 平成 5 年から 58 名の死亡退所があり, 原因疾 患としては肺炎が 28 名， $48.3 \%$ を占めた。このうち施 設内死亡者は平成 5 年 1 名, 6 年 3 名, 7 年 3 名, 8 年 2 名, 9 年 6 名と計 15 名あり, ターミナルケアとし て看取った入所者を 7 名経験した。アンケート結果よ り，増えつつある施設内死亡については，いいこと (17.9\%)，やむを得ないこと $(67.9 \%)$ と計 $85.8 \%$ の 賛同が得られた。家族の医師に対する抢まかせ主義に ついては $60.7 \%$ がしとせず，鼻腔栄養は誤曣性肺炎 の予防に $85.7 \%$ が適応とし，35.7\%が根気よく経口摄 取への努力を続けるべきとした．肺炎治療のための入 院については施設内で治療が可能ならそれが望ましい $(57.1 \%)$, 発症前の生活レベルを考え適応を決める $(50.0 \%)$ ，入院させるべき $(39.3 \%)$ ，抗生物質の点滴 などはしない方がよい (14.3\%) と意見は分かれた。 終末期の希望につき $92.9 \%$ が本人・家族に対し入所す る際にきいておく，終末期の治療の方向性の決定は $71.4 \%$ が本人・家族の意思を尊重し医師・看護婦・ケ アワーカー・その他のチームで下すべきとした。

結論：(1) ターミナルケアを考えた施設内死亡の入 所者が増えつつある。（2）ケアワーカーに対するアン ケート調査から，特養でのターミナルケアに対して $85.8 \%$ が賛成であった。（3）本人・家族の意向の確認 やインフォームドコンセント，治療方針の決定など今 後さらなるシステム整備を要する。

\section{1. 外来患者の終末期のケアに関する意識調査}

東京都老人医療センター

松下 哲, 稲松 孝思, 橋本 肇 高橋龍太郎，大川真一郎，高橋 忠雄
森 真由美，木田 厚瑞，小沢 利男

目的：高齢者の終末期のケアでは，人生を通じて終 末に関する考えを持つに至り，一方既に病気を持ち， 頭脳は明晰な時期の老人の意識調査を参考にすること ができる。

対象および方法：外来通院患者について，希望する 終末場所が，がんの終末期（余命 3 力月）と仮定した 場合の延命治療，告知，早期がんの場合の告知，配偶 者ががんの終末期の場合の配偶者への告知，更に脳が 障害されて自分の意思を表明できない場合 $(A)$ の強制 栄養, 痛みのケア, 肺炎や出血, 腸閉塞が起こった場 合の治療についてアンケートで回答を求めた。推計学 的検定は SAS を用いた。

結果： 562 人平均 $73.4 \pm 8.6(\mathrm{SD})$ 歳より回答を得た。 終末場所の希望は自宅 $64 \%$ であった。がん終末期での 病名告知は $60 \%$ が希望し, 治療ではある程度自然の寿 命に任せて欲しいは $80 \%$, 延命治療に徹するのは $9 \%$ であった。早期がんでの告知は $65 \%$ で，終末期と比べ て有意の増加に至らなかった。また配偶者が終末期の 場合，配偶者への告知は $42 \%$ と低下した。加齢と手段 的 ADL 非自立で, 余命日数告知, 早期がんについては 告知は低下した。Aの状態での強制栄養は経鼻管 $5 \%$, 点滴 $39 \%$, 胃ろう $3 \%$, 何もしないは $42 \%$ で, 痛みのケアは麻薬使用 $40 \%$, 我慢する $35 \%$, 麻薬は使 用しない $7 \%$ ，何もしない $8 \%$ だった。その場合肺炎 にかかった時の抗生物質投与は $39 \%$, 出血時の輸血は $30 \%$ ，腸閉塞時の手術は $37 \%$ の希望であった。

考案と結論：今までの一般の調査と本調査を比べる と早期がんの告知が低い他は, 差よりも同質性が目立 ち，精神的に自立している高齢者では若中年と同じよ うに告知を扱うべきである，家族との関係では告知に 老人に対する差別が関わって来得るギャップがある. A の場合のケアや治療においては実際に行っている ものと解離がみられ，実際のケアの情報の開示が必要 と思われる。

\section{2. 横浜市西区の老人健診15年の follow-up 成績} （5 歳階級別, 5 年ごとに区切って)

横浜市西区 M.C.

山岡 三郎, 鈴木 潔, 林 敬治

全田 慶夫，坪井宏，長谷川国光

東大・医・衛生

松下 裕子

杏林大・保健・保健管理野山修

目的：1970年以降，65歳平均余命の伸びが注目され 
ているが，臨床医の立場から見ても高齢者の健康度は 高まったように感じられる。この背景を探る一つの試 みとして，1970年代と1980年代の15年間にわたって集 められた老人健診データの変化を解析した。

対象と方法：対象は，横浜市西区医療センターで実 施された老人健診(1972年 6 月〜 1987 年 5 月の 15 年間) の受診者で，初診時年齢が65〜 79歳だった 4,999 人 (男 2,067 人，女 2,932 人）である。健康度の変化を観察す るための検査項目として, 赤血球数, へマトクリット 值, ヘモグロビン, 総蛋白, アルブミン, 総コレステ ロール, 最大血圧, 最小血圧, 心電図所見, BMI を選 んだ。健康度の変化を観察するために，対象者を 5 年 幅の受診時期(A：1972年 6 月～77年 5 月，B：1977年 6 月〜 82 年 5 月, C : 1982年 6 月〜 87 年 5 月)によって 3 群に分け, 初診時年齢を 5 歳階級別 ( I : 65〜 69歳, II : 70〜 74歳, III：75〜 79歳) の 3 群に分けた。世代 間の比較（3つの年噛階級ごとに $\mathrm{A}$ 群と C 群の平均 值・割合を比較), 及び同一世代における加噛変化の観 察 (A・I 群と C・III群の平均值・割合を比較) は男女 別に行った.

結果：赤血球数, ヘマトクリット值, へモグロビン, 総蛋白, アルブミン, 総コレステロールのいずれでも， $\mathrm{A}$ 群より $\mathrm{C}$ 群の平均值が有意に大であった。 又, $\mathrm{A} ・$ I 群より C・III群の平均値が有意に大である場合が多 かった. BMI と心電図所見では, A 群と C 群, 及び A・ I 群と C・III群の間で有意差はなかった。最大血圧で は, $\mathrm{A}$ 群より $\mathrm{C}$ 群, また $\mathrm{A} ・ \mathrm{I}$ 群より C・III群の平均 值が有意に小さかった。最小血圧では, $\mathrm{A}$ 群と $\mathrm{C}$ 群の 有意差は一部しか認められず，A・I 群より C・III群の 平均值のほうが有意に小さかった，以上，男女ともに 似た傾向を示し, 受療群と非受療群に分けても同様で あった。

考察：食生活を初めとする生活環境, 及び保健医療 環境の改善が検査データに反映した結果と考えられ る.

\section{3. 老年者の健康度に関する地域比較研究一高知県} 香北町と秋田県若美町との比較 I-ADL と QOL

高知医大老年病科

松林 公蔵, 和田 知子, 藤沢 道子

$\begin{array}{rr}\text { 奥宮 } & \text { 清人, 大崎 } \text { 康史, 土居 義典 } \\ \text { 秋田脳研 } & \text { 平田 } \text { 温, 鈴木 一夫 }\end{array}$

目的：高知県香北町（人口約 6,000, 高齢化率 $33 \%$ ) と秋田県若美町（人口約 8,000 , 高秢化率 $21 \%$ ) におい
て, 65歳以上の老年者の $\mathrm{ADL}$ 自立度と QOL の実態を 比較検討した。

対象と方法：対象は香北町在住老年者 1,770 名 (男： 女 $=772: 998$, 平均734.7歳) と若美町在住老年者 1,106 名(男: 女 $=423: 683$, 平均73.7歳)である. アンケー 卜調查により ADL 8 項目 (歩行, 階段昇降, 食事, 更 衣, 排泄, 入浴, 整容, 服薬) について完全自立から 介助までを 4 段階評価し $3-0$ 点にスコア化した. $\mathrm{ADL}$ 自立とは ADL スコア24点満点と定義した.QOL については, 主観的健康度, 食欲, 睡眠, 気分, 記憶, 家族関係, 友人関係, 経済状態, 生活満足度, 幸福度 の10項目を Visual Analogue Scale（VAS）を用いて 評価した.

結果：両地域に共通して,ADL が完全に自立してい る老年者の割合は加齢とともに低下した，全老年者の うち $\mathrm{ADL}$ が自立している老年者の割合は, 若美町 $77 \%$, 香北町 $85 \%$ と有意に後者で高かった。一方 QOL については, VAS 10項目のすべてにおいて若美町が香 北町よりも有意に高得点を示した。

考察・結論：高歯化率が高い香北町のほうがより高 齢化率の低い若美町よりも老年者の ADL 自立度が高 い事実は注目に值する。すなわち，高齢化率が高いこ とはそのまま虚弱老年者の割合が高いことを意味せ ず, 高齢者の自立度を維持するためにはなんらかの保 健的介入効果の余地があることが示唆された。

一方, ADL 自立度とは逆に QOL が若美町で有意に 高かった事実は，風土習慣や県民性の相違による可能 性を残すが, 客観的健康度の向上と主観的 QOL は必 ずしも相関しないことが示唆された。

\section{4. 老人人口増加は日本を疲弊させるか?}

東北大学医学部老人科

佐々木英忠, 関沢 清久, 矢内 勝

荒井 啓行, 山谷 睦雄, 大類 孝

2020 年には, 老人人口が日本総人口の $25 \%$ に達し, 三人の若者が一人の老人を支えなければならないとさ れている. 15歳から64歳までの生産人口は，1920年に $60 \%$ ったものが, 現在 $70 \%$ とピークに達し，30年後 には $60 \%$ へと減少して行く. しかし, 就業人口をみる と 1920 年の $48 \%$ から，今日の $48 \%$ となり，30年後女性 の $65 \%$ が欧米並に働くとすると就業人口は $44 \%$ に落ち つく，老人の $30 \%$ が働きたいと言っているので，これ も入れると $54 \%$ に達する. 従って, 昔から日本人は, 約半数が㗢いてきたのであり,将来もそうであるので, 
老人人口の増加は, 日本を疲弊させることはないと考 えられる。

\section{5. 聴力の加跉変化に関する研究一 66,000 人の大規 模集団での追跡}

国立長寿医療研究センター疫学研究部

下方 浩史, 安藤富士子, 岩尾 智

(社)オリエンタル労働衛生協会

\section{葛谷 文男}

目的：聴力は感覚機能の老化の指標としてすでに利 用されてきているが, 聴力の老化に関する疫学的研究 は, その大多数が横断的観察の結果に基づいたもので あり，綐断的検討はほとんどない. 加齢と聴力との関 係について大規模集団での追跡デー夕を用いて検討す るとともに, 高齢者の QOL に深く関連する聴力損失 の危険因子についても検討を行った。

方法：1989年から1996年までの 8 年間にわたって, 名古屋市内で人間ドックを受診した14歳から94歳まで の男女 65,995 人である。そのうち $52.7 \%$ が複数年受診 し, 複数年受診者の平均受診回数は 3.8 回であった。聴 力はオージオメーターを用いて $1,000 \mathrm{~Hz}, 2,000 \mathrm{~Hz}$, $4,000 \mathrm{~Hz}$ で測定し, 左右の計測值のうち良い方の值を 採用した. 8 年間の延べ 162,378 回の聴力測定について 出生コホート別・性別に聴力の加齢変化をプロットし, 聴力の変動におけるコホート効果 (Cohort effect), 時 代による効果 (Perios effect), 加齢による効果 (Aging effect）を検討した。 また聴力損失の危険因子の検討に ついて血圧, 而糖能, 血清脂質, 喫煙, 飲酒, 血液像 との関係を重回㷌モデルを用いて検討した。

結果：男女とも30歳代から明らかな加齢による聴力 低下が認められた。この聴力の低下は $1,000 \mathrm{~Hz}, 2,000$ $\mathrm{Hz}, 4,000 \mathrm{~Hz}$ と男女とも高音になるほど大きかった. 男性での聴力低下は高音域で女性よりも大きかった が, 出生コホートによる加齢変化の差はどの周波数で もほとんどなかった。しかし聴力の測定手技によると 思われる時代効果が，どの周波数でもわずかではある が認められた。聴力低下の危険因子として喫煙, 肥満, 耐糖能低下, 低 HDL コレステロール血症, 多血症など が得られた。

結論：加齢による聴力変化は出生コホートによる差 が少なく, 高音域で加齢変化が大きかった。また聴力 低下の危険因子としていくつかの有意な要因を得るこ とができた。
96. 後期老年者の血圧值と 3 年後の認知機能との間 にはJ-Curve 関係を認める一香北町研究一

高知医大老年病科

奥宮 清人, 松林 公蔵, 和田 知子 大崎 康史，土居 義典

東京都老人医療センター 小沢 利男

目的：高血圧と認知機能低下や痴呆との関連は議論 のあるところだが，最近， 70 歳時の高血圧が $10 〜 15$ 年 後の痴呆の発症と関連があることが報告された、我々 は, 75 歳以上の後期老年者の血圧と認知機能の関係を 調べるため, 3 年間追跡調査した.

対象と方法：香北町在住後期老年者 155 人, 男 58 人, 女97人，平均年齢78歳を対象とした. 1992年と1995年 に血圧測定と Mini Mental State テスト (MMSE) を 施行した。1992年の収縮期血圧（SBP）のレベルで4 群に分類した. $\mathrm{SBP}<125$ (第 I 群, $\mathrm{n}=38$ )， $125 \leqq$ $\mathrm{SBP}<150$ (第II群, $\mathrm{n}=63$ ), $150 \leqq \mathrm{SBP}<175$ (第III群, $\mathrm{n}=40), 175 \leqq \mathrm{SBP}(\mathrm{mmHg})$ (第IV群, $\mathrm{n}=14)$.

結果：1992年には, MMSEは 4 群で有意差はな かった。各群の降圧剂服用者率は $13.5 \%, 47.5 \%$, $40.0 \%, 71.4 \%$ で 3 年後も各群の比率に有意な変化を 認めなかった。 3 年後の MMSE は, I, II, IV群で有 意に低下した。I 群, 27.2 $\rightarrow 26.3$, II群, 28.2 $\rightarrow 27.6$, IV群, $27.9 \rightarrow 26.1$ (点) $(\mathrm{p}<0.05$, paired t-test). ᄂ かし, III群は変化しなかった $(27.5 \rightarrow 27.9)$.さらに, 3 年間の MMSE 值の低下は, I, IV群がIII群に比べ て，有意に大きく $(\mathrm{p}<0.05$, Fisher PLSD, ANOVA : $\mathrm{p}<0.05)$, 血圧值と MMSE 值の低下は, J-Curve 関係 を認めた。

考察及び結論：後期老年者は, 高血圧とともに低血 压も 3 年後の認知機能低下と関連があった. 多発性脳 梗塞を有する高血圧者の過度の降圧は認知機能低下に つながるという報告もあり, 我々の結果もそれを支持 する結果であった。

\section{7. 心筋梗塞死亡率におよぼす血清脂質の動態}

藤枝市立総合病院, 志太医師会, 藤枝市保健 センター

\section{中澤 浩二}

目的：心筋梗塞死亡率への血清総コレステロールお よび HDL-C の関与について疫学的に検討した。

方法：人口 12 万 6 千人の F市において1987年より 1995 年まで 9 年間でのべ 192,576 人（男 64,593 人，女 127,983 人)の空腹時採血をおこない血清コレステロー 
ルを測定した. HDL-C は1992年より1995年までのべ 95,514 人（男 32,492 人，女 63,022 人）の測定をした. 心筋梗塞で死亡したものを性, 年代別に1987年より 1995年までしらべた。

結果：血清コレステロール平均值は1987年より 1995 年まで196.8, 200.0, 199.0, 200.5, 200.5, 203.8， $200.9,200.0,203.5 \mathrm{mg} / \mathrm{d} l$ と 1992 年をピークに変動し た.男性では185.6, 189.2, 188.7, 190.6, 191.4, 193.3, 191.0, 190.3, $194.7 \mathrm{mg} / \mathrm{d} l$ であった. 女性では202.6, 205.5, 205.5, 204.1, 205.4, 204.9, 209.0, 205.9, $207.7 \mathrm{mg} / \mathrm{d} l$ と変化した $(\mathrm{p}<0.01) . H D L-C$ は1992年 より全体では57.5，57.4，57.4，57.8mg/d l。男性は $54.4,54.4,54.4,53.9 \mathrm{mg} / \mathrm{d} l$ と 1995 年に減少した。 女性では $58.9,58.9,58.9,59.7 \mathrm{mg} / \mathrm{d} l$ と 1995年に増 加した $(\mathrm{p}<0.01)$. 心筋梗塞による死亡者の年代別, 男/女比は40歳代よりそれぞれ8/1，16/4，37/13，74/ 40, 66/93人で男性に有意に多い. 人口 10 万人あたりの 心筋梗塞死亡者は HDL-C を測定しはじめた1992年か ら男性では33.4, 18.1，47.2，57.0，女性では28.8， 22.4, 33.0, 17.1人で男性では HDL-C の低下とともに 心筋梗塞死の増加をみ, 女性では HDL-C の上昇とと もに心筋梗塞死の減少をみた。

結論：1987年より血清総コレステロールは年々増加 し1992年にピークになりその後 2 年間減少し1995年に は再増加した。HDL-C は男性では1995年に心筋梗塞 死亡者が増加した．女性では1995年に HDL-C は増加 し同時に心筋梗塞死亡者は減少した. HDL-C の変動 は血清コレステロールの変動より心筋梗塞死に関連が 見られた。

\section{8. 久山町の地域住民における血漿ホモシステイン} 濃度と心血管病の関連

九州大学第二内科

清水 治樹, 加藤 功, 清原 裕
岩本 廣満, 中山 敬三, 久保 充明
谷崎 弓裕, 下野 淳哉, 山縣 元
有馬 久富, 井林 雪郎, 藤島 正敏
冢製薬佐賀研究所

上野 裕文, 木村 靖浩

目的：近年, 血中ホモシステイン (Hc) の上昇は, 脳卒中, 虚血性心臟病など動脈硬化性疾患の危険因子 とする報告が散見される. そこで福岡県久山町の一般 住民の断面調査において, 血中 Hc 濃度と脳梗塞およ び心筋梗塞頻度の関係を検討した。
方法 : 久山町在住の脳梗塞発症者 75 名と心筋梗塞発 症者 21 名を対象とした。対照として, 平成 8 年の久山 町成人検診の受診者から性・年齢を対応させた心血管 病の既往歴のない378名を選び, 発症群との間で血漿 $\mathrm{Hc}$ 濃度を比較した. 血漿 Hc は, 空腹時採血後に直ち に冷却遠沈にて分離した血漿を用い, 液体クロマトグ ラフィー法にて測定した。関連因子として年齢, 性, 高血圧, 糖尿病, 血清コレステロール, BMI, 飲酒, 喫煙, 血清クレアチニンに加え, Hc の代謝に影響を与 える葉酸, ビタミン $\mathrm{B}_{6}$, ビタミン $\mathrm{B}_{12}$ の血中濃度も測 定し検討に用いた。

成績：男性の血漿 Hc 值は女性より高く, 男女とも 加齢とともに有意に上昇した。 また血漿 $\mathrm{Hc}$ 值は葉酸, ビタミン $\mathrm{B}_{6}$, ビタミン $\mathrm{B}_{12}$ の血中レベルと逆相関を示 した. 脳梗塞群の $\mathrm{Hc}$ の中央值は $14.1 \mu \mathrm{mol} / \mathrm{L}$ で対照 群の $12.3 \mu \mathrm{mol} / \mathrm{L}$ に比べて有意に高かった.一方, 心筋 梗塞群の血墏 $\mathrm{Hc}$ 值も対照群より高かったが有意差は なかった $(12.4 \mu \mathrm{mol} / \mathrm{L}$ 対 $11.8 \mu \mathrm{mol} / \mathrm{L})$. また, 全対 象者を $\mathrm{Hc}$ 值の三分位で 3 群に分けた検討では, Hcレ ベルの上昇とともに脳梗塞の頻度は有意に上昇した。 多変量解析により, 他の 120 関連因子を補正してもこ の関係に変りはなかった。 心筋梗塞にも同様の傾向が 見られたが有意な変化ではなかった。

結論：血中 $\mathrm{Hc}$ 值の上昇は脳梗塞の危険因子となり うることが示唆された. 今後追跡研究において両者の 関係を検討する必要がある。

\section{9. 最近の地域住民における脳梗塞発症の危険因} 子 : 久山町研究

九州大学医学部第二内科

加藤 功, 清原
中山 裕, 岩本
廣満
谷崎 弓裕, 下野
淳哉, 山縣

目的：近年わが国では，降圧治療の普及により高血 圧頻度が減少し, 逆に食生活を含む生活様式の西洋化 に伴って肥満, 高脂血症, 而糖能異常などの代謝異常 が増加するなど, 心血管病危険因子のレベルが変貌し つつある。 そこで本報告では, 福岡県粕屋郡久山町で 継続されている疫学調査の成績を用いて, 最近の一般 住民における脳梗塞発症の危険因子を検討した。

対象および方法：1983年の久山町成人検診を受診し た満40歳以上の住民のうち, 脳卒中と心筋梗塞の既発 症者を除く2,459名を対象とし, 1983年11月より10年間 
追跡した。詳細な病歴調査, 頭部 CT 所見を含む臨床 記録,さらに死亡者については病理解剖記録をもとに 脳卒中発症の有無・病型を決定した。追跡開始時の年 齢，血圧值，心電図異常 (左室肥大または ST 低下), BMI, 血清総コレステロール (TC), HDL コレステ ロール (HDLC), 動脈硬化指数 \{(TC-HDLC) / HDLC \}, 耐糖能異常, 飲酒・喫煙習慣を危険因子の解 析に用いた。

結果：追跡期間中に男性48名，女性54名が脳梗塞を 発症した。年歯調整した脳梗塞罹患率（対 1,000 人年） はそれぞれ4.3，3.1であった. 年齢調整後の検討では, 男女とも耐糖能異常, 高血圧（SBP/DBP $\geqq 160 / 95$ $\mathrm{mmHg}$ または降圧薬服用) が脳梗塞発症の有意な危険 因子となった。さらに男性では多量飲酒（日本酒換算 で一日1.5合以上) が，女性では動脈硬化指数が有意な 危険因子となった. 多変量解析では年齢, 耐糖能異常, 高血圧が男女で有意な危険因子となった，男性では喫 煙が，女性では動脈硬化指数と心電図異常が危険因子 となる傾向があった，また，1960年代の集団と比べる と, 高血圧者では脳梗塞発症のリスクが大幅に減少し た。

結論：最近の久山町住民では, 脳梗塞の危険因子と して, 高血圧の影響が薄れ, 耐糖能異常をはじめとす る代謝異常の影響が増大した。

\section{0.「百寿者」の死因一病理解剖の立場から一}

東京都老人医療センター・病理 ${ }^{1)}$, 東京都老人 総合研究所・臨床病理 ${ }^{21}$

江崎 行芳 ${ }^{11}$ 沢辺 元司 ${ }^{11}$

新井 富生 ${ }^{1)}$ 田久保海誉 ${ }^{2)}$

目的：「老衰死」の有無を考察するため, 老年者の最 高グループである百歳老人（百寿者） 42 剖検症例の死 因を検討した。

対象：最近までのおよそ20年間に剖検された百寿者 の42症例. 男性 が 9 例（100 106歳），女性33例 (100〜105歳) で, この性別比は全国平均（1対 4) に ほぼ一致する。

結果：臨床経過や諸検査值を充分に考慮して剖検結 果を検討すると, これら42症例の全てに妥当な死因が あった。肺炎は24例 $(57.1 \%)$ に認められ，これらの 多くが誤嚥に起因するものと思われる。このうち主た る死因となったのは15例（全体の35.7\%）であった. 敗血症性ショックが死因となったのは13例（31.0\%） で，原因疾患は腎需腎炎が最も多い( 7 例)，食物䛊嬹
や痰喀出困難による窒息死は 5 例 $(12.0 \%)$ ，心夕ンポ ナーデなどによる心不全は 4 例 $(9.5 \%)$ であった。い わゆる脳卒中は 2 例のみ $(4.8 \%$ ：出血と梗塞）で, 残 る 3 例 (7.1\%) が栄養不良による.「栄養不良」とし たものは，臙下障害や食思不振を伴う著明な䇔瘦があ り, 電解質異常や心不全を来して死亡するものである. 覀性腫崵は16例（38.1\%）に認められ，このうち 5 例 が重複癌で, 合計22病巣であった。しかし，主たる死 因となり得るものは 1 例も存在せず，全てが前述の死 因のいずれかを持っている，内訳は大腸癌 8 例，膀胱 癌 3 例, 肺癌 2 例, 胃癌 2 例, その他 7 例であるが, 主病変として患者を苦しめたと思われるものは 4 例 $(18.2 \%)$ にすぎなかった。手術などの治療後に再発の 無かったものが 8 例あり, 癌巣が微小であったり早期 のものであったのが10病巣である.

結語：百寿者の 42 剖検症例を臨床的・病理解剖学的 に検討した結果，その全てに妥当な死因が見出だされ た。厚生省は，「他の原因を全て除外し，明らかに自然 死と判断された場合」を「老衰」死と説明しているが, その様な死は存在しない.

\section{1. 高齢者剖検例の臨床的有用性についての検討 札幌慈啓会病院内科}

川原田 信, 佐藤 保則

目的：近年, 剖検率の低下が著しく剖検の意義に再 検討がせまられている，当院は成人病・老年病の専門 病院として診療してきているので当院の高齢者剖検例 を対象にその臨床的有用性について検討する。

対象と方法：対象は1986〜1995年までの10年間の当 院における総死亡609例のうち剖検231例（剖検率 $37.9 \%$ ：男性95例，女性136例，平均年歯80.5歳)であ る.これらの症例について臨床診断と剖検診断の比較, 高齢者剖検例の特徴などを検討した，尚，臨床診断名 の分類は Merck Manual（第15版）によった。

結果：剖検231例のうち剖検によりその主死因を明 らかにしえたのは218例 $(94.4 \%)$ であり，残る13例 （5.6\%）は主死因は明らかでなかった。この13例の生 前臨床診断は呼吸器疾患が 6 例（肺炎 5 , 気管支喘息 1 例）と最も多かった。主死因からみた臨床診断と剖 検診断との比較では, 両者が一致した疾患は呼吸器疾 患 (肺炎など)，悪性腫瘍，心・血管疾患（心筋梗塞） など，中枢神経疾患（脳梗塞など）に多かった。一方， 一致しなかった疾患は臨床診断に関係なく剖検により 心・血管疾患（心筋梗塞，腹部動脈瘤破裂，うっ血性 
心不全など)，悪性腫瘍，感染症(敗血症，肺膿瘍，横 隔膜下膿瘍など), 呼吸器疾患 (肺炎, 肺梗塞など) と 診断された症例が多かった。また潜在癌，多重癌につ いては潜在癌28例（12.1\%：甲状腺，結腸各 6 例で最 多), 多重癌 3 例 (1.3\%：5 重癌，3 重癌，2 重癌各 1 例）が剖検により発見された。

老年医学的意義：高齢者の病態の複雑さは剖検に よってもその主死因を明らかにしえなかった13例 (5.6\%) をみても判断しうるが，高齢者に臨床診断を 的確に行うことのむづかしさは今回の剖検成績の検討 より, 加齢に伴う全身の動脈硬化症の進展, 免疫能の 著しい低下にその基礎があるものと思われ，高齢者の 臨床に有用な所見を得ることができた。

\section{2. 東京都23区内での高齢者の急死について一第一} 報一

\section{東京都監察医務院濱松 晶彦}

目的：東京都23区内における65歳以上の高䶨者は如 何なる原因で急死しているのか，また死因にどのよう な変遷があるのかを知るために，死因を病死，交通事 故などの災害死，自殺，その他の死に分類して，昭和 23 年から平成 6 年まで検案対象となった事例を検討し てみた。

対象：昭和 23 年から平成 6 年まで検案対象となった 267,388 件中の 65 歳以上の高齢者 72,881 件を対象とし た.

結果：1. 総検案数は昭和 23 年の392件から平成 6 年 の4,295件まで増加した.74歳以下例は223件から 1,631 件に増加, 75歳以上例は54件から2,664件に増加し75歳 以上例の増加がめだった。

2. 病死の件数は 45 件から 3,610 件まで増加した。 74 歳以下の例は 35 件から 1,302 件に, 75歳以上例は 10 件か ら2,308件に増加し，75歳以上の増加がめだった。件数 ばかりではなく病死総数に対する65歳以上の高齢者の 割合も増加し，なかでも75歳以上の増加が著しい.

3. 災害死は61件から312件に増加した。74歳以下例 は52件から125件に増加，75歳以上 9 件から187件に増 加し74歳以下では横這い傾向にあるのに対し，75歳以 上例は増加してきている。

4.自殺は140件から 260 件となった。

5.その他の死は，31件から113件となった。

考察：東京都23区内の検案件数は年毎に増加し, 65 歳以上の高齢者の増加が著しい。このことは東京都 23 区も高齢者社会に突入したことを反映していると思わ
れる。また65歳以上の高齢者の中でも75歳以上の増加 がめだつことは，超高齢者社会になりつつあることを 暗示しているのかもしれない.今後は死因別の検討を して行く予定である.

\section{3. 老化の縦断調査（東浦町スタディー）の研究報}

\section{告一第 2 報：独自調査の報告一}

国立療養所東名古屋病院内科 山田 英雄 国立療養所中部病院内科, 神経内科*

遠藤 英俊, 井形 昭弘*

昨年に続き，「老化に関する縦断的研究」のパイロッ トスタディー（東浦町スタディー）第 2 報として, 独 自調査の成績を報告する. 独自調査として行った，(1) 社会心理テスト (平成 5 年)，（2）骨塩定量(女性）(平

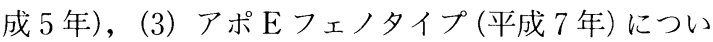
て報告する。

1. 社会心理学的調査：A. PGC スケールによる生 活満足度テスト (17項目)，B．情感テスト（12項目）, C. 自己評価テスト (10項目) の 3 種類を自主記入によ るアンケート調査により検討した。40歳代と60歳代の 男女について世代間の差についても検討した，各個人 のこれらの成績と縦断調査成績の共通及び独自調査項 目の各データとの関連性について有益な資料が得られ ると期待する。

2. 骨塩定量の成績：女子 32 名の骨塩濃度を簡易骨 塩定量器（Lunar 社アキレス）により測定した。加齢 に伴いstiffness が有意に減少を示した。但し，病的異 常値を示したものはなかった。閉経期を挟んで著明な 骨塩量の低下が起こることを如実に示した。

3.アポEフェノタイプの調査成績：80名全員のア ポEフェノタイプについてフェノタイピングアポ $\mathrm{E}$ キット（常光株式会社）を用い測定した。結果は E 3/ $2: 2$ 例, E $3 / 3: 61$ 例, E 4/2：1 例, E 4/3：15例, E 4/4：1例であり,これらのフェノタイプの出現頻度 に男女差はなかった。アポ $\mathrm{E} 4$ はアルツハイマー型痴呆 の原因遺伝子ではなく危険因子の一つと考えられる が，補助診断法の一つとして本縦断調査の長期成績と の関連が注目される。

本報告では, 過去 4 年間に行った老化の縦断調査(東 浦町スタディー）の独自調査の主なものについて報告 し, 得られた成績と今後の長期縦断調査成績との関連 性について考察した。

104. 共通病床（一般救急病床）における老年者救急 


\section{入院患者の検討}

東京都老人医療センター内科 久保木謙二

目的：最近当センターでは老年者救急患者の入院床 として, 内科系救急当番病棟, CCU 以外に外科病棟の 一部に共通病床（8床）を開設した。本研究ではこの 共通病床に打ける一般老年者救急入院患者の現況を明 らかにする。

対象と方法：平成 8 年 2 月より 10 月までに共通病床 に入院した65歳以上の患者，連続156例(男68例，女88 例，平均年齢80歳）につき，症状，診断，入院までの 期間，患者の背景，経過につき検討した。

結果：初発症状としては多い順に呼吸困難29例, 発 熱19例，麻晫12例，食欲低下11例，嘔気一嘔吐 7 例で あり，その他多岐にわたっていた。入院時の意識状態 は昏睡 1 例，半昏睡 3 例，傾眠20例，錯乱 1 例で意識 障害 (一) は106例であり，約 $20 \%$ に意識障害がみられ た。ADL は侵たきりが $28 \%$ ，車椅子 $9.3 \%$ ，杖歩行 $20.6 \%$ ，独歩 $42.1 \%$ であった。痴呆は高度 $6.5 \%$ ，中等 度 $16.8 \%$, 軽度 $29 \%$, 知呆（一） $47.7 \%$ であった。発 症より入院までの期間は 1 日以内 $34.5 \%, 2$ 日 $11.7 \%$, 3 日7.6\%であったが, 1 週間以上が $13.8 \%$, 徐々に症 状悪化した例 $9.7 \%$ と，入院までの経過が長い傾向が あった。転帰は死亡 $2 \%$, 悪化3.3\%, 不変 $26.7 \%$, 軽 快 $68 \%$ であり, 入院後の診断は, 呼吸器系 43 例 (27.6\%), 消化器系25例 (16\%), 神経系17例 (10.9\%), 循環器系15例 (9.6\%), 腎一尿路系 8 例 (5.1\%)であっ た。多い疾患としては肺炎一気管支炎32例，脳梗塞12 例, 心不全 9 例, イレウス 6 例, 尿路感染症 6 例であっ たが，他に骨折が11例と多くみられた。

結論：共通病床における老年者救急入院患者の症状 は多岐にわたるが呼吸困難，発熱，麻痺等が多く，入 院時に意識障害, ADL 低下, 痴呆を認める例が高率で あった。発症より入院までの期間は長い傾向がみられ， 診断は各領域にわたるが，多い疾患としては肺炎，気 管支炎，脳梗塞，心不全等であった。

105. 麻酔症例に占める老年者・高齢者の割合の推移 東京大学医学部付属病院手術部 ${ }^{11}$, 麻酔学教 室 $^{21}$

長田 理 ${ }^{1}$ 花岡 一雄 ${ }^{2}$

目的：麻酔科で管理された手術症例に占める老年者 の割合を 6 年間にわたり調査し, 推移について検討し た。

方法：当施設で施行された麻酔科管理の手術症例を
対象に，1991年 1 月から1996年までの 6 年間について 年間麻酔症例数（ただし1996年分については抄録作成 時までの症例数）に占める老年者（65歳以上79歳以 下)・高齢者（80歳以上）の割合を調査した。

結果：1991年では年間麻酔症例 3,513 例に対して,老 年者 484 例 (14.2\%)，高齢者 61 例 (1.7\%)，合計 $15.5 \%$ であった.1992年はそれぞれ3,556例，583例(16.4\%)， 63例 $(1.8 \%)$ ，合計 $18.2 \% ， 1993$ 年は 3,570 例，619例 $(17.3 \%) ， 74$ 例 $(2.1 \%) ，$ 合計 $19.4 \% ， 1994$ 年は3,629 例，606例(16.7\%)，80例 (2.2\%)，合計 $18.9 \% ， 1995$ 年 は3 322 例， 680例 (18.3\%)，77例 $(2.1 \%)$, 合計 $20.3 \% ， 1996$ 年 は 3,547 例，705例 $(19.9 \%) ， 78$ 例 (2.2\%), 合計 $22.1 \%$ でった。

老年医学的意義：老年者では活動性が劣っており， 日常生活に支障がないことは心機能，呼吸機能など蔵 器機能が手術・麻酔に十分耐えられることを意味しな い. 人為的に外科的侵襲を加える手術中の全身管理を 担当する麻酔科では, 臟器予備能が低下している老年 者・高齢者に麻酔を施行するにあたり細心の注意が必 要であることは周知の事実である。本研究により，当 施設において手術麻酔の対象患者に占める老年者・高 齢者の実数挹よび割合が増加していることが確認され た。この結果をもとに，八イリスク患者に対する麻酔 管理体制の充実が必要と考えられた。

\section{6. 生命予後に対する動脈硬化危険因子集積の影 響；性差と加齢による差異一北海道循環器疫学調査よ り一}

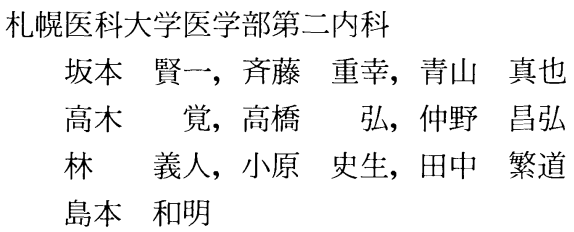

目的：脳血管疾患と心疾患死亡に対する動脈硬化危 険因子集積の関与を前向き疫学調査の成績から解析, 特に性差の影響と中年者と高年者の差異について検討 した。

対象・方法：1977年より北海道 S・T 2 町村において 継続中の前向き循環器疾患疫学調査では, 初年度に無 作為抽出した40～64歳の住民1,996名のコホートを設 定した。今回は1995年 8 月31日までに生命予後調査を 終了し得た1,819名（追跡率91.1\%，男性871名，女性 947 名，初年度平均年噛 $50.9 \pm 7.0$ 歳）を解析の対象と し，初年度年齢に61歳未満の中年者男女（男性761名, 
女性841名）と61歳以上の高年者男女（男性110名，女 性106名)の 4 群に分類.さらに初年度の喫煙, 高血圧, 糖尿病, 高脂血症 (総コレステロール $220 \mathrm{mg} / \mathrm{d} l$ 以上ま たは中性脂肪 $150 \mathrm{mg} / \mathrm{d} l$ 以上), 肥満 (BMI : 26.4 以上) の有無の 5 項目を各対象で調査, 危険因子を 0 ないし 1 個有するリスク少数群 (以下少数群), 危険因子を 2 個以上有するリスク多数群 (以下多数群) に2 分した。 脳血管疾患死または突然死・心筋梗塞を含めた心臟死 を脳血管・心疾患死と定義しこの累積生存率 (生存率) を検討した。解析は Kaplan-Meier 生存分析を用い, 有 意差検定は log-rank 法によった。

成績: 危険因子の集積は男性少数群306名, 女性少数
群470名, 男性多数群 565 名, 女性多数群477名. 初年度 より1995年 8 月31日までの死亡者は256名. 男女全体で は少数群に比して多数群で生存率の低下が認められ, 男性でその傾向はより顕著であった。また，男性高年 者では多数群で少数群に比し有意に生存率が低値で あったが, 男性中年者では少数群と多数群で生存率に は差異がなかった。 女性若年者では多数群の生存率が 少数群より低值だが, 女性高年群では差異を認めず男 性とは異なる傾向を示した。

結論：生命予後に対する危険因子の集積の影響は男 女で異なり, 高齢者では男性において危険因子の集積 が強く生命予後に関与していると考えられた。 